\section{Buffalo Pound Park}

A spanking new exhibit room has recently been added to the park entry office, and the major exhibit is very nearly complete. The theme of the center's exhibits will be "The Bison and Man", and the major exhibit is a lifesized replica of a buffalo pound, with a huge bull just entering the crude corral.

The Buffalo Coulee Nature Trail is a half-mile route starting from the Maple Vale Campground. It follows the bottom and side of a ravine, and features the typical flora and fauna of these important wildlife refuges. The Big Valley Trail is longer; it descends into a wide valley that runs down to Buffalo Pound Lake.

\section{Battlefords Park}

The Wintergreen Trail is a tribute to park staff who have independently developed this excellent trail. The 3/4mile route leads up a forested coulee, and returns across a prairie hilltop. Onsite interpretation is presented by typed labels protected by wooden "flipboards".

\section{Condie Nature Refuge}

For the past three years season: naturalists have provided group tour guided walks and other programs fo groups visiting the refuge. Many priva groups and hundreds of school childre have been able to take advantage of th service.

The Nature Center Exhibits explai the glacial origin of the Condie terrait and discuss the natural and huma history of grassland and marsh.

The Boggy Creek Nature Trail rur along the valley of this slow-movin stream. Interpretive panels give adde information on subjects of interest.

Much still needs to be done to brin about the kind of Interpretive Prograt that we all would like to see. With th continuing support of the Natur? History Societies, school teachers an Outdoor Education Associations, w should be able to develop a program i Saskatchewan that rivals the finest th: exists anywhere. We're working on it!

\title{
PEST CONTROL
}

\author{
by MAURICE E. TAYLOR*
}

Over the past several years people have become increasingly aware of environmental concerns regarding the use of chemical pesticides. Reaction to this concern has resulted in much anxiety and confusion for the general public and the homeowner in particular. The homeowner now feels that he is confronted with a dilemma: can he safely combat pests in and around his home and property without hazard to himself and the environment, or must he stand by and watch insects and other pests ruin his garden and the landscape?

While this concern is understandable, the situation really is not that serious. Home ground plantings of or-

* Research Station Canada Agriculture, University Campus, Saskatoon, Saskatchewan. namentals, fruits and vegetables can $t$ safely protected from serious pest injui by good management practices and, necessary, by the proper use pesticides that have little or no harmf effect on the environment.

The number of non-chemical methor used to manage or control pests can 1 as numerous as the people involve Many gardeners have their own "pel methods that may work well for the but not prove satisfactory to others. $\mathrm{Th}$ following are a few effective and pra tical management practices that he prevent or reduce damage from garde pests:

(1) Resistant plant material - Alway 
ow varieties of fruits, vegetables and namentals that are recommended for ur area by provincial horticulturists. any of the recommended varieties ve some resistance to pests or, because ey are adapted to the area, are better le to tolerate moderate infestations of sects or plant diseases.

(2) Cultural methods - Use cultural actices that provide plants with the st growing conditions possible. gorous, healthy plants are less likely suffer pest injury. Weeds should be iminated by timely tillage because they t only rob moisture but may harbour sect pests and plant diseases. initation is very important. Plant bris may contain overwintering incts or disease organisms and should erefore be removed from the garden in e fall or buried or used in a compost le. Wherever possible, rotation of garen crops is a good practice. Potatoes in rticular should not be grown on the me soil two years in succession.

(3) Mechanical control - The use of echanical devices such as barriers, aps, nets and even hand collection ofn offers quick and positive results. The me gardener with relatively few plants in put to use a number of effective and onomical methods of this kind. Cardard or metal collars placed around ansplants will prevent cutworms from tting off the plants. Hand picking of terpillars of various kinds - hornprms, woollybears, armyworms, etc. ten can be just as practical as using an secticide. Slugs can be trapped and llected under pieces of board or bark.

(4) Biological control methods atural control forces including rasites, predators and pathogens play important role in keeping insects unr control. Birds should be encouraged d predatory insects such as ground etles and ladybird beetles should not killed. The practice of importing dybird beetles and praying mantis for lease in gardens has not proven very eful; however, native ladybird beetles ten become abundant enough to play a ynificant part in controlling aphids.

Naturally-occurring bacterial and ngal diseases of insects only oc- casionally result in effective control of infestations. However, one bacterium, Bacillus thuringiensis, has been propagated by man and can be applied on gardens and other crops to control several kinds of caterpillars without hazard to man or wildlife. It will be available commercially in Canada this year.

Control with Pesticides - There are times when non-chemical methods of control do not perform as expected and pest epidemics may develop in spite of the gardener's best efforts. An insecticide may then be required to bring the pest population down to a tolerable level.

The objective of control should be to reduce the population to a nonepidemic level, not necessarily to eliminate it. It should be remembered that not all insects are pests; in fact, many of them are beneficial. Pesticides should be used with discretion, therefore, and directed as far as possible only at the pest species.

The choice of pesticides should be limited to those with moderately low human and animal toxicity so that they can be used safely on gardens and around the home. They must also possess another essential characteristic: the ability to degrade or break down into non-toxic substances soon after application. Such degradable products do not affect the environment adversely.

Among the readily available insecticides and miticides that have these characteristics and are recommended for use in Saskatchewan gardens are: carboryl, diazinon, kelthane, malathion, methoxychlor, pyrethrins, and rotenone. The chances of adverse hazards arising from the proper use of such pesticides is nil.

Integrated control - A method widely used in the solution of pest problems is integrated control. This is the judicious use of a combination of non-chemical or management practices and pesticides. This technique appears to offer the best solution to pest control with the least adverse effect on the environment. 